\title{
MYTH OF EUROPEAN DARK AGE (5TH-15TH CENTURY) SCIENTIFIC KNOWLEDGE STAGNATION: CRITICAL STUDIES OF SCIENTIFIC IDEA INTERACTIONS BETWEEN THE LATE MEDIEVAL THEOLOGIAN AND EARLY MODERN PHILOSOPHER
}

\author{
Prof. Jaw CHUNG-CHONG ${ }^{1}$, Amran MUHAMMAD ${ }^{2}$, \\ ${ }^{1}$ Universiti Teknologi Malaysia, ${ }^{2}$ Asia e University Malaysia, \\ Malaysia, \\ E-mail: ${ }^{1}$ chongchung4526@ gmail.com, ${ }^{2}$ amran.muhammad@aeu.edu.my
}

\begin{abstract}
Within common historical context, most historians consider the European renaissance age as age of origins of modern scientific knowledge, also, they assume European Medieval Age (5th-15th centuries) as age full with scientific knowledge ignorant. This research paper gives important historical review about interactions of scientific idea between the late medieval theologian and early modern philosopher. However, most previous research was more emphasized on scientific knowledge development during the age of renaissance and age of enlightenment without considering the contribution of early medieval age theologian. By examining this historically event with critical review, I do give some clarification to such pervasive myth by using qualitative research methodologies, which involving analyst of historical facts from primary resources and secondary resources such as archives, journals, book chapters, and published research paper. This research challenges the argument that scientific knowledge development only happened since renaissance age. In the comparatives studies, I found out that early medieval theologian, from William of Ockham to Gabriel Biel, who did played an important role of influencing early modern philosopher, Rene Descartes to David Hume, with scientific ideas. Such finding does give a significant clarification to the myth of medieval Europe scientific knowledge stagnation in modern historical debate.
\end{abstract}

Keywords: Medieval age; scientific knowledge stagnation; theologian; philosopher; influences; renaissance age; enlightenment age;

\section{HISTORICAL INTRODUCTION}

Medieval age Europe can be considered as a significant era that last from the fall of Roman Empire to age of renaissance (Grant, 1996). Most historians agree that the rise of Dark Age, which is a sarcastic term for medieval age, is a negative impact caused by the fall of Roman Empire. Common stereotype historical fact that we can found at European Dark Age were the Black Death that killed the majority European population, corruption of church authority and societal obsession of irrational religious dogma. Because of such negative phenomenon, medieval age always categorized as Dark Age by most historian. For them, Dark Age is an era when European society experiencing development degradation within social, politics, scientific and economic context. 
However, most historians forgot that even though medieval age experienced development degradation, there are scientific activities carried out by some Christian theologian (Hannam, 2009). Catholic theologian during that era wrote a lot of philosophical ideas which contribute to scientific development, where they contribute to religious knowledge and scientific knowledge side by side together in their writing. They wrote religious scripture, and, they also wrote philosophical ideas for society (Dixon, 2005). It is their philosophical ideas which influenced societal thinking during that era. Such influence does spark up scientific idea and speed up the scientific idea gradually, leading to scientific revolution during the end of renaissance (Hannam, 2009).

One of the significant issues which is always manipulates by some historian is the scientific knowledge stagnation during the medieval age, or, Dark Age. According to them, European Dark Age didn't experience any scientific knowledge development at all. In contrast, Dark Age society was more emphasized to religious activities rather than scientific activities. The most schematic answer provided by them is, not many significant scientific scholars which can be identified during that era compare with ancient Greek era, such as Archimedes (Brooke, 2014). They have to understand that religious theologian did play a role as natural philosopher who wrote philosophical ideas that influence scientific development.

\section{MYTH OF MEDIEVAL EUROPEAN DARK AGE}

Most historians portrayed Medieval Europe as a religious continent, where its populations were church-centered since childhood. Catholic Church authority plays important role in baptizing, marriage, and spiritual aspect. Almost every European life aspects were dominated by church doctrines and conservative dogmas (Dixon, 2005). Churches authorities also dominated education from schools to universities, as the main educational provider to whole society. Because of such bigger dominant role in European society, most European society was so obsessive to catholic churches dogma until the breaking of any minor rules of religious preaching would be considered as heretical. Hence, European society would preferred religious dogma in life problem solving rather than applying secular scientific knowledge (Draper, 2009).

Such obsessions of religious dogmas did solved some life spiritual problem in moral character building, but, it did not solving critical problem, such as Black Death that killed millions of European, unexplained astronomical phenomenon and unexplained life phenomenon. There were some scientists who conducting research in finding practical ways to dealing with such critical problem. Unfortunately, their scientific findings were not accepted by Church authority. Condemnation by church authority happened because of the research finding is contradicting with the bibles' preaching. Scientific thinking is considered radical during that era and it can be classify as religious heretical (Gregory, 2016).

Most Historians also making an irrational speculation for the Dark Age, for example, medieval Europe did not having many interactions with Islamic civilization, which is experiencing Golden scientific era. The rise of Islamic civilization had causing the down fall of European civilizations, by using the Holy War at Jerusalem as excuse. The only interaction was the warfare between the crusaders and the Islamic knights at Middle East. They considered knowledge transfer interaction not happened at all between Europe and Islamic civilization. The obsession of Christianity dogmas by European did stop them from interacting with the Muslims for few centuries. 


\section{LATE MEDIEVAL THEOLOGIAN AND MODERN PHILOSOPHER SCIENTIFIC IDEAS INTERACTION}

William of Ockham (1214-1294), is the most renowned theologian during the late medieval age by his preaching of philosophy 'Ockham's Razor' (Spade, 2006). Ockham's razor gave him the title of Father of modern epistemology, Father of modern philosophy and father of Nominalism. His writing, Summa logicae, describes about medieval knowledge of logic and contains philosophy of nominalism. Nominalism describes how universe exists in humanity. By using this philosophy, Autrecourt (1295-1369) wrote and proposed Skeptism , which describe the importance of philosophical logic thinking instead of using religious doctrine. Gabriel Biel (1410-1495), a nominalist and Ockham's follower, applying the view of Ockham in political economy in his writing, Expositio Canonis Missae, which emphasized the price of commodity, is determining by human needs.

Francisco Suarez (1548-1617), who received influence from Ockham, wrote Metaphysical Disputations, a writing that challenges Aristotelian metaphysics by using Nominalism (Evan, 2001). Ockham's razor did influence Thomas Hobbes (1588-1679), who wrote Leviathan. The writing do laid a foundation for modern political philosophy, a preaching that emphasized the separation of government and religion. Hobbes also received influence from Pierre Gassendi (1592-1655), a theologian who introduce improved Aristotelian version of Atomism. Gassendi also introduce empirical method and experimental analysis that laid a good foundation for modern science experimental methodology.

Francis Bacon (1561-1626) has been called the father of empiricism. His works emphasized the possibility of scientific knowledge based only upon inductive reasoning and careful observation of nature. He proposed that accurate scientific finding could be achieved by applying of a skeptical and methodical approach. He invented the Baconian method, a skeptical methodology makes Bacon the father of the scientific method. This method was a new rhetorical and theoretical framework for science, which is used by the scientists as references in the following era, especially, Issac Newton, John Locke, Robert Boyle, Thomas Hobbes and Voltaire.

Rene Descastes (1596-1650), is known as father of modern philosophy and father of modern mathematics. He wrote Meditations on First Philosophy, which describes the interaction between mind, body, and god. As the inventor of the Cartesian coordinate system, Descartes founded analytic geometry in mathematics. He is also regarded as first thinker to create frameworks known as methodological skeptism for the development of scientific knowledge. By using the frame work, Robert Boyle (1627-1691), known as father of modern chemistry, had wrote Sceptical Chymist. The writing had challenged traditional views on the nature of chemical elements and their composition. Influenced by the writing Meditations on First Philosophy, Nicholas Malebranche (1638-1715) proposed and wrote Treatise of Human Nature which spreading the doctrine of vision of god, Occasionalism and theodicy.

Isaac Newton (1643-1727), who is the father of modern science and father of classical mechanics, had written Philosophie Naturalis Principia Mathematica. His writing describing the law of universal gravitation and three laws of motion, and it had laid a good ground work for Newtonian mechanics. He discovers light composed of corpuscles, developed calculus and improved binomial theorem.

Newton's writing did influence George Berkeley (1685-1753) in natural philosophy. Berkeley published his writing, An Essay Towards a New Theory of Vision, in which he discussed the limitations of human vision and improved the corpuscles theory that the human eye sight are not material objects, but rather, light and color. David Hume (1711-1776) is 
renowned in modern world for his improved version of philosophical empiricism, skepticism, and naturalism. In his writing, A Treatise of Human Nature, he emphasized the psychological basis of human nature is that the mind, which consists of perceptions, or the mental objects inside it. He also emphasized that human knowledge derives solely from experience. This places him together with Francis Bacon, Thomas Hobbes, John Locke, and George Berkeley, as an Empiricist.

\section{CONCLUSION AND CLARIFICATION OF THE MYTH}

development in the following centuries especially the renaissance age and enlightenment age. Early medieval theologian, William of Ockham, played an important role as a pioneer, or, origin of modern scientific thinking in his philosophical writing, known as Ockham's razor. Most of his writing did influence the scientific thinking of fellow theologian since early medieval age until early renaissance age. Rene Descartes, known as father of modern philosophy did gain significant philosophical influences from him. Also, father of modern science, Isaac Newton, did received philosophical influences from most of the early medieval theologian, starting from William of Ockham. Such indirect influence did speed up scientific revolution since Enlightenment Age.

The critical studies did debunk the myth of scientific knowledge stagnation during the European Dark Age. Most historical arguments emphasized that Dark Age is an era where European society experiencing civilization degradation, a society which is too obsessive with religion, church authorities conflicting with scientists and lack of interactions with other civilizations. By using the examples of theologian philosophical contribution, it did provided a good clarification review to debunk such pervasive myth speculating by most modern historians. Indirectly, early medieval theologian did provide philosophical ideas that influence the scientific thinking of early modern philosophers.

Finally, the argument of medieval age scientific knowledge stagnation is no more acceptable by using the concrete example stated in this study. Modern historians should give more emphasized in European medieval age research since some great philosophers in this era did produce significant writing, which is considered radical, but, do provided advance philosophical framework viewpoint for the scientific development in the mankind history. European Dark age is no more considered as irrelevant era; in contrast, it has to be given more attention in modern historical studies. An extra effort should be given to rethinking, research and review the important role of early medieval theologian by most modern historical scholars.

\section{BIBLIOGRAPHY:}

[1] Brooke, J., (2014). Science and Religion: Some historical perspective: Cambridge University Press.

[2] David, C., (2013). The Cambridge history of science: Medieval science: Cambridge University Press.

[3] Draper, J.D., (2009). History of the conflict between science and religion: Cambridge University Press.

[4] Dixon, T., (2005). Science and Religion: A short introduction. London: Oxford University Press. Evan, G.R., (2001). The Medieval Theologians : An Introduction to Theology in the Medieval Period : Blackwell Publishing.

[5] Gregory, D., (2016). Galileo and the conflict between science and religion: Routledge Press.

[6] Grant, E., (2010).The Nature of Natural Philosophy in the Late Middle Ages (Studies in Philosophy and the History of Philosophy): Catholic University of America Press

[7] Grant, E., (1996). The foundations of modern science in the middle ages: Their Religious, Institutional, and Intellectual contexts: Cambridge University Press. 
[8] Hannam, J., (2009). God's philosopher: How medieval world Laid the foundations of modern science: London: Icon Book.

[9] Hannam, J., (2009). The genesis of science: How the Christian middle ages launched the scientific revolution: Regnery Publishing.

[10] Henry, J., (2008). The scientific revolution and origins of modern science: Cambridge University Press.

[11] Linberg, D.C., (1992). The beginnings of western science: The European scientific tradition in philosophical, Religious, and Institutional Context: 600 B.C. to A.D. 1450: University of Chicago Press.

[12] Spade, P.V., (2006). The Cambridge Companion to Ockham: Cambridge University Press.. 